\title{
Relationship between IQ and academic performance of medical students.
}

\begin{abstract}
1. MBBS, M.Phil (Physiology) Assistant Professor Physiology Ameer ud Din Medical College, PGMI, Lahore.

2. MBBS, M.Phil (Physiology) Assistant Professor Physiology Ameer ud Din Medical College, PGMI, Lahore.

3. MBBS, M.Phil (Physiology) Assistant Professor Physiology Ameer ud Din Medical College, PGMI, Lahore.

4. MBBS, M.Phil (Physiology) Senior Demonstrator Physiology Lahore Medical \& Dental College, Lahore.

5. MBBS, M.Phil (Physiology) Demonstrator Physiology Ameer ud Din Medical College, PGMI, Lahore.

6. MBBS, M.Phil (Physiology) Professor \& Head Physiology Ameer ud Din Medical College, PGMI, Lahore.
\end{abstract}

Correspondence Address:

Dr. Komal labal

Department of Physiology

Ameer ud Din Medical College, PGMI,

Lahore.

komaln69@gmail.com

Article received on:

$18 / 11 / 2019$

Accepted for publication:

$11 / 07 / 2020$

\section{INTRODUCTION}

The status of a person in a society is indicated by his or her education which is related to his income and wellbeing. The mode for the evaluation of ones level of intelligence in many societies is examination. In our society also the key criteria to judge ones potential and capacity is by the academic achievements. ${ }^{1}$

Intelligence by definition is the ability to utilize information, memory, understandings, experiences, logics, thoughts and conclusion in order to unknot tribulations, and acclimatize to new situations. ${ }^{2}$ A German psychologist William Stern in 1912 invented the abbreviation "I.Q.," an interpretation of the German Intelligent-Quotient ("intelligence quotient). According to him an intelligence of a person level can be measured as a percentage of their estimated "intellectual age" and their chronological age. ${ }^{3} \mathrm{IQ}$ of a person is also explained as his ability to understand complicated ideas, overcome hurdles, adjust effectively to the environment, involve deeply in various forms of reasoning, and learn from knowledge. ${ }^{4}$

Academic achievement has a fundamental consign in education and in the studying process. Variables like, type of school, socioeconomic status of students, education of the parents, intelligence, personality etc. effect the performance and academic achievement of students. Intellectual growth depends on ecological \& biological factors. ${ }^{5,6}$

Although intelligence and achievement are two different things, but they are strongly related to each other. ${ }^{7}$ Intellectual power such as long-term memory, ability to think theoretically whereas 
nonintellectual power such as inspiration, selfcontrol both have impact on student's academic performance. Authorized procedures of IQ measurement exist since the early 1900s, which have been used in many researches for the evaluation of intellectual ability. ${ }^{8}$ Good academic performance is not achievable in the absence of intelligence but on the other hand those having high intelligence does not ensures high academic performance. $^{6}$

Different studies have been done on the relationship between intelligence and academic achievement in past few years. Some researchers think that the association between intelligence and achievement is reciprocal. ${ }^{9}$ Still others emphasize that intelligence is causally related to achievement. Laidra, et al., 2007 stated that the achievements of students depends intensely on their cognitive abilities. ${ }^{10}$

Intelligence quotient among the males and females have been studied by researchers, according to which there is no gender difference in general intelligence ${ }^{11}$ but contrary to these some studies reported that a difference is present between males and females. ${ }^{12}$ Some studies show gender differences in specific thinking abilities. Some report females whereas other report males ${ }^{13}$ but many of studies find no gender distinctions in intelligence. ${ }^{14}$

Due to diversity in relationship between academic achievement and intelligence this study was planned.

\section{MATERIAL \& METHODS}

The sample of the study were selected from second year students of Ameer Ud Din Medical College / PGMI Lahore through simple convenience sampling technique. The sample size came out to be 75 but for better results it was raised to 100 students. A good rapport was established with the subjects and it was assured to them that their responses will not be revealed to any one and will be used only for study purpose.

Online Wechsler Adult Intelligence Scale (WAIS) was used to find out IQ of students. The original
WAIS was published in February 1955 by David Wechsler. It is currently in its 4th edition (WAISIV). It's an online test and includes 20 questions and scored automatically. The test was performed by students in PGMI digital library.

Previous academic records of the students before their admission in medical college were considered as aggregates. Whereas the test results of second year MBBS during the year were taken as marks.

The collected data was analysed by using SPSS version 22. Correlation was done by using Spearman Correlation. Data was compared by using Mann Whitney $U$ test and independent ttest.

\section{RESULTS}

A total of 100 students in the age range of 20-21 years participated. There were 46 males and 54 females. The mean IQ of the whole study group was 93.2 \pm 19.6. Majority of the students of the study had a normal IQ in range of 90-109 (TableII). A non significant correlation was seen when IQ was correlated with marks and aggregates respectively (Table-III).

A statistically significant difference ( $p=0.04$ ) between IQ of boys and girls was found with males having mean IQ of $97.4 \pm 22.7$ as compared to females $89.6 \pm 15$ (Figure-1). No significant difference was observed in academic achievements of male and female students (Table-IV).

\begin{tabular}{|c|c|}
\hline IQ & Interpretation \\
\hline 130 and above & very superior \\
\hline $120-129$ & superior \\
\hline $110-119$ & High average \\
\hline $90-109$ & Average \\
\hline $80-89$ & Low average \\
\hline 7079 & Boderline \\
\hline 69 and below & Extremely Low \\
\hline \multicolumn{2}{|c|}{ Table-I. Interpretation of IQ scores } \\
\hline
\end{tabular}




\begin{tabular}{|l|c|c|}
\hline \multicolumn{1}{|c|}{ IQ Range } & Frequency & Percentage \\
\hline $25-49$ & 1 & $1 \%$ \\
\hline $50-69$ & 9 & $9 \%$ \\
\hline $70-79$ & 14 & $14 \%$ \\
\hline $80-89$ & 22 & $22 \%$ \\
\hline $90-109$ & 37 & $37 \%$ \\
\hline $110-119$ & 11 & $11 \%$ \\
\hline $120-139$ & 3 & $3 \%$ \\
\hline 140 and above & 3 & $3 \%$ \\
\hline
\end{tabular}

Table-II. Frequency distribution according to IQ range of whole study group

\begin{tabular}{|l|c|c|}
\hline \multicolumn{1}{|c|}{ IQ } & rho & P-Value \\
\hline Marks & 0.055 & 0.584 \\
\hline Aggregates & 0.150 & 0.137 \\
\hline
\end{tabular}

Table-III. Correlation of IQ with marks and aggregates of whole study group

\begin{tabular}{|c|c|c|c|}
\hline Variables & $\begin{array}{c}\text { Males } \\
\mathbf{N = 4 6}\end{array}$ & $\begin{array}{c}\text { Females } \\
\mathbf{N = 5 4}\end{array}$ & P-Value \\
\hline \#Agregates & $\begin{array}{c}87.65 \\
(87.16-88.47)\end{array}$ & $\begin{array}{c}87.69 \\
(87.20-88.18)\end{array}$ & 0.281 \\
\hline \#Marks & $\begin{array}{c}54.00 \\
(47.75-58.00)\end{array}$ & $\begin{array}{c}55.00 \\
(52.00-59.00)\end{array}$ & 0.787 \\
\hline *IQ & $97.41 \pm 22.78$ & $89.64 \pm 15.78$ & 0.048 \\
\hline
\end{tabular}

Table-IV. Comparison of study variables between males and females of study population

\#Comparison was done by Mann Whitney U

*Comparison was done by Independent sample t Test

\section{DISCUSSION}

This study was conducted on 100 medical students to see the relationship of their academic performance with $I Q$ and also to evaluate any gender difference in IQ. Students are admitted on merit from all over Punjab and belong to a diverse background in terms of schools attended, parental education, socio-economic status etc. Therefore academic records before admission in medical college were considered as aggregates. Considering first year as adaptation year to a different mode of learning with more emphasis on self directed learning the tests results of second year MBBS, during the year were taken as marks. So academic achievement was obtained by taking previous academic records of the students before their admission in medical college along with test results of second year MBBS during the year. The reason for taking both was to evaluate their cognitive as well as their practical skills. As both these skills are the main constituents of intelligence. Majority of the students had an $\mathrm{IQ}$ in range of 90 to 109 (average and above average IQ) and only 3\% had gifted/genius or extraordinary IQ.

When the IQ was compared between the boys and girls of study group a significant value of $p=0.04$ was seen. The mean IQ boys was (97.4 \pm 22.7$)$ and mean IQ of girls was (89.6 \pm 15.5$)$. Similar results were reported by Sophie et al. (2006). They revealed gender differences on different aspects of the intelligence, boys performed better than females when evaluated for information, arithmetic and matrix reasoning. ${ }^{15}$ Bartholomew stated that males have relatively larger brains as compared to females. ${ }^{16}$ Adrian and Buchanan in 2005 revealed a difference in intelligence among the males and females with males being more intelligent than females. ${ }^{17}$

In our study no significant difference was observed in academic achievements of male and female students. Similar results have been shown by Deary et al., 2003, Wendy and Johnson 2007 and Habibollah, et. al 2008. ${ }^{18-20}$

Ritu et al (2013) reported that the academic achievements of the students are influenced by their intelligence. The child who has higher IQ levels shows better academic achievement as compare to the child having an average IQ. ${ }^{21}$

Academic achievement and intelligence have a complex relationship. Our results showed that males have higher IQ but it has no relationship with academic achievement. The academic performance of the students with average or low IQ was similar to the academic performance of students with higher IQ which could be due to hard work of students with low or average IQ. Therefore Intelligence quotient cannot be related to academic performance. In order to determine the effect of Intelligence quotient and gender on academic achievement more studies should be carried out. 


\section{CONCLUSION}

Although males have high IQ but non-significant result was seen when $I Q$ and academic achievement was correlated in the students of medical college. Hard work of the students with average or low IQ could be the reason that their was no difference in the academic achievement when they were compared with the students having higher IQ.

Copyright@ 11 July, 2020.

\section{REFERENCES}

1. Battle $\mathrm{J}$, Lewis $M$. The increasing significance of class: The relative effects of race and socioeconomic status on academic achievement. Journal of poverty. 2002 Mar 1; 6(2):21-35.

2. Legg S, Hutter M. A collection of definitions of intelligence. Frontiers in Artificial Intelligence and applications. 2007 Jun 7; 157:17.

3. William T. Dickens and James R. Flynn, "The IQ Paradox: Still Resolved," Psychological Review 109, no. 4 (2002). Available at psychology.wikia.com/wiki/ Intelligence_quotient.

4. Yu TY, Chen KL, Chou W, Yang SH, Kung SC, Lee YC, Tung LC. Intelligence quotient discrepancy indicates levels of motor competence in preschool children at risk for developmental delays. Neuropsychiatric disease and treatment. 2016; 12:501.

5. Yesikar V, Guleri SK, Dixit S, Rokade R, Parmar S. Intelligence quotient analysis and its association with academic performance of medical students. International Journal of Community Medicine and Public Health. 2017 Feb 5; 2(3):275-81.

6. Patel D. Correlational study of intelligence and academic achievement of school going children in relation to gender, habitat, type of schools and socioeconomic status. Journal of information, knowledge, and research in humanities and social sciences. 2011:1(2)24-7.

7. Kaya F, Juntune J, Stough L. Intelligence and its relationship to achievement. http://dx.doi. org/10.17051/io.2015, 14:(3), 1060-1078.

8. Duckworth AL, Seligman ME. Self-discipline outdoes IQ in predicting academic performance of adolescents. Psychological science. 2005 Dec; 16(12):939-44.
9. Naderi $H$, Abdullah R, Aizan HT, Sharir J. Intelligence and academic achievement: An investigation of gender differences. Life Science Journal. 2010; $7(1): 83-7$.

10. Laidra K, Pullmann H, Allik J. Personality and intelligence as predictors of academic achievement: A cross-sectional study from elementary to secondary school. Personality and individual differences. 2007 Feb $1 ; 42(3): 441-51$.

11. Jackson DN, Rushton JP. Males have greater g: Sex differences in general mental ability from 100,000 17-to 18-year-olds on the Scholastic Assessment Test. Intelligence. 2006 Sep 1; 34(5):479-86.

12. Furnham A, Fong G, Martin N. Sex and crosscultural differences in the estimated multi-faceted intelligence quotient score for self, parents and siblings. Personality and Individual Differences. 1999 Jun $1 ; 26(6): 1025-34$.

13. Hyde JS. The gender similarities hypothesis. American psychologist. 2005 Sep; 60(6):581.

14. Lynn R, Irwing $P$, Cammock $T$. Sex differences in general knowledge. Intelligence. 2001 Jan 1; 30(1):2739.

15. Sophie P, Danielle VD, Dolan CV, De Geus EJ, Colom R, Boomsma DI. Sex different on the Dutch WAIS-III. Intelligence. 2006; 34:273-89.

16. Halpern DF, LaMay ML. The smarter sex: A critical review of sex differences in intelligence. Educational Psychology Review. 2000 Jun 1; 12(2):229-46.

17. Furnham A, Buchanan T. Personality, gender and selfperceived intelligence. Personality and individual differences. 2005 Aug 1; 39(3):543-55.

18. Deary IJ, Thorpe G, Wilson V, Starr JM, Whalley LJ. Population sex differences in IQ at age 11: The Scottish mental survey 1932. Intelligence. 2003 Nov 1 ; 31(6):533-42.

19. Johnson W, Bouchard Jr TJ. Sex differences in mental abilities: $g$ masks the dimensions on which they lie. Intelligence. 2007 Jan 1; 35(1):23-39.

20. Naderi $\mathrm{H}$, Abdullah $\mathrm{R}$, Tengku Aizan $\mathrm{H}$. Male versus female intelligence among undergraduate students: Does gender matter. Asian Journal of Scientific Research. 2008; 1(5):539-43.

21. Chandra R, Azimmudin S. Influence of intelligence and gender on academic achievement of secondary school students of Lucknow City. IOSR Journal of Humanities and Social Science (IOSR-JHSS) Volume. 2013; 17:09-14. 


\begin{tabular}{|c|l|l|l|}
\hline \multicolumn{3}{|c|}{ AUTHORSHIP AND CONTRIBUTION DECLARATION } \\
\hline Sr. \# & \multicolumn{1}{|c|}{ Author(s) Full Name } & \multicolumn{1}{|c|}{ Contribution to the paper } & Author(s) Signature \\
\hline 1 & Komal lqbal & Author \\
2 & $\begin{array}{l}\text { Sana Rasheed } \\
\text { Chaudhry } \\
3\end{array}$ & $\begin{array}{l}\text { Hifza Noor Lodhi } \\
4\end{array}$ & Author \\
5 & Shagufta Khaliq & Author \\
6 & Muneeza Taseer & Author \\
\hline
\end{tabular}

